\title{
Reversible Inactivation of the Isocitrate Dehydrogenase of Escherichia coli ML308 during Growth on Acetate
}

\author{
By P. M. BENNETT* \\ University Institute of Microbiology, DK-1 353, Copenhagen, Denmark \\ AND W. H. HOLMS \\ Department of Biochemistry, University of Glasgow, Glasgow G I $28 Q Q$
}

(Received I August 1974)

\begin{abstract}
SUMMARY
During aerobic growth of Escherichia coli ML308 on acetate as sole carbon source, the apparent synthesis of isocitrate dehydrogenase was repressed relative to cultures on other carbon sources, such as glucose, which do not employ the glyoxylate bypass as an anaplerotic sequence. When cells were removed from an acetate medium, or when compounds were added which made the operation of the glyoxylate bypass unnecessary, the activity of isocitrate dehydrogenase rapidly increased 3- to 4-fold but fell again on restoration to an acetate medium. Changes in activity were rapid and, furthermore, could be demonstrated in the absence of protein synthesis. It is thus improbable that the mechanism involved degradation or de novo synthesis of the enzyme protein. Oxaloacetate and glyoxylate showed concerted inhibition of isocitrate dehydrogenase which could be relieved by dialysis. Because extracts of low enzyme activity, derived from acetate-metabolizing cells, could not be stimulated by dialysis or by addition of a wide range of metabolites, it is unlikely that low molecular weight, freely dissociable effectors were responsible for stimulation or inhibition of activity.

Control of isocitrate dehydrogenase permitted the efficient utilization of acetate as sole source of carbon and energy but preserved the capacity of the cell to respond rapidly to an improvement in nutritional conditions. A limited survey showed that the mechanism is common but not universal among strains of $E$. coli and occurs in at least one strain each of Klebsiella aerogenes, Salmonella typhimurium and Serratia marcescens.
\end{abstract}

\section{INTRODUCTION}

Growth on acetate, as sole source of carbon and energy, requires the anaplerotic sequence known as the glyoxylate bypass (Kornberg, 1966). This pathway competes with the tricarboxylic acid cycle in that isocitrate lyase and isocitrate dehydrogenase share a common substrate, thus creating a situation where some form of control might be expected.

During aerobic growth on glucose, acetate accumulates in the medium (Britten, 1954), and following exhaustion of the sugar the cells adapt to the acetate (Holms \& Bennett, I97I). As metabolism of acetate proceeds, the activity of isocitrate dehydrogenase declines and is maintained at a low level until the acetate is exhausted, when enzyme activity is largely regained. However, addition of chloramphenicol at the end of growth on limited glucose prevents adaptation to acetate and no loss of isocitrate dehydrogenase activity occurs, but oxidation of acetate continues (Holms \& Bennett, I97I). These observations suggest that

* Present address: Department of Bacteriology, The Medical School, Bristol BS8 ITD. 
the loss of isocitrate dehydrogenase activity and subsequent maintenance at a low level of activity during metabolism of acetate are a consequence of adaptation to acetate as a carbon and energy source.

Since the glyoxylate bypass and the tricarboxylic acid cycle compete for the available supply of isocitrate, the flow of carbon into the anaplerotic pathway is favoured when isocitrate dehydrogenase activity is decreased. In principle, the mechanism employed could involve control of enzyme synthesis (or destruction). Alternatively, activity could be modulated by low molecular weight effectors or by a reversible modification of the enzyme protein itself. This paper describes investigations of these possibilities. Parts of this work have already been presented at a meeting of the Society (Bennett \& Holms, 1970).

\section{METHODS}

Organisms, methods and chemicals. These were as described by Holms \& Bennett (I97I), with minor modifications which are described where appropriate. The organisms used are listed in Table 4. When cells were adapted to acetate, the time of the three serial subcultures was lengthened to allow for the increased generation time, and the concentration of $\mathrm{MgSO}_{4} \cdot 7 \mathrm{H}_{2} \mathrm{O}$ in the medium was lowered to $0.5 \mathrm{mM}$ to avoid precipitation of magnesium phosphate during the later stages of growth.

Release of isocitrate dehydrogenase activity for enzyme studies in vitro. Cells were harvested by centrifuging ( $10000 \mathrm{~g}$ at $4{ }^{\circ} \mathrm{C}$ for $10 \mathrm{~min}$ ), washed in $\frac{1}{4}$ vol. ice-cold growth medium lacking a carbon source, and resuspended at I to $4 \mathrm{mg}$ wet $\mathrm{wt} / \mathrm{ml}$ in ice-cold $0.15 \mathrm{M}-\mathrm{NaCl}$ containing bovine plasma albumin $(5 \mathrm{mg} / \mathrm{ml})$. Cells were disrupted by sonication as previously described (Holms \& Bennett, I97I) and the sonicated suspensions were diluted, as required, with $0 \cdot I_{5} \mathrm{M}-\mathrm{NaCl}$ containing bovine plasma albumin $(5 \mathrm{mg} / \mathrm{ml})$.

Heat inactivation of isocitrate dehydrogenase. For heat treatment of isocitrate dehydrogenase, cells were resuspended, after washing, in ice-cold $0.15 \mathrm{M}-\mathrm{NaCl}$ to $5 \mathrm{mg}$ wet wt/ml and were disrupted as before. Volumes $(\mathrm{I} \cdot 0 \mathrm{ml})$ were held at the required temperature for $10 \mathrm{~min}$ and were then cooled in an ice-water bath. Volumes $(0.2 \mathrm{ml})$ of the heated sonicated suspensions, made up to $\mathrm{I} \cdot 0 \mathrm{ml}$ with $0.15 \mathrm{M}-\mathrm{NaCl}$ containing bovine plasma albumin $(5 \mathrm{mg} / \mathrm{ml})$ were pre-incubated at $27^{\circ} \mathrm{C}$ and assayed for isocitrate dehydrogenase activity as described by Holms \& Bennett (197I).

Specific activity of isocitrate dehydrogenase. All specific activities are expressed as enzyme units (Holms \& Bennett, 197I) per mg bacterial protein, with the exception of the data presented in Table 4 where specific activities are expressed as enzyme units per culture extinction unit $\left(E_{420}\right)$.

\section{RESULTS}

\section{Stability of isocitrate dehydrogenase after growth on limited glucose}

Following the cessation of growth on limited glucose $(2 \mathrm{~mm})$ the activity of isocitrate dehydrogenase fell and then partially recovered approximately $3 \mathrm{~h}$ later (Fig. I). Addition of chloramphenicol (0.3 mM, a concentration which completely inhibits protein synthesis) at the end of growth prevented this loss. When acetate (I mM) was added to the culture after recovery of enzyme activity there was a second, very rapid loss of isocitrate dehydrogenase activity which was unaffected by simultaneous addition of chloramphenicol (Fig. I). Enzyme activity again subsequently recovered, although recovery was delayed in the presence of the drug. The delay may have resulted from a slower rate of acetate utilization imposed by the inhibition of protein synthesis. 


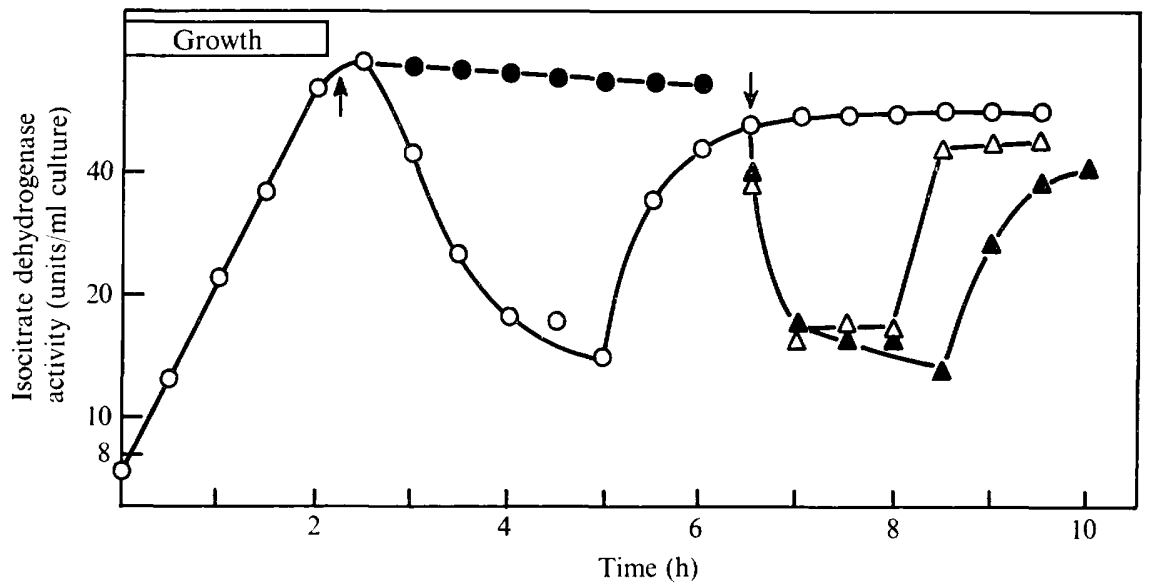

Fig. I. Isocitrate dehydrogenase activity following addition of I mm-acetate, $0.3 \mathrm{~mm}$-chloramphenicol, or both, after cessation of growth on limited glucose $(2 \mathrm{~mm})$. The cells were grown for 24 generations on 2 mM-glucose (Holms \& Bennett, 197I) before inoculation into fresh medium. $O$, Control (no addition); $\Delta$, acetate (I mM) added approximately $4 \frac{1}{4} \mathrm{~h}$ after growth ceased ( $\downarrow$ ); , chloramphenicol $(0.3 \mathrm{~mm})$ added at the end of growth $(\uparrow) ; \boldsymbol{\Delta}$, acetate (I mM) and chloramphenicol (0.3 mM) added approximately $4 \frac{1}{4} \mathrm{~h}$ after growth ceased $(\downarrow)$. The bar at the top left-hand corner represents the time during which growth (increasing culture turbidity) occurred.

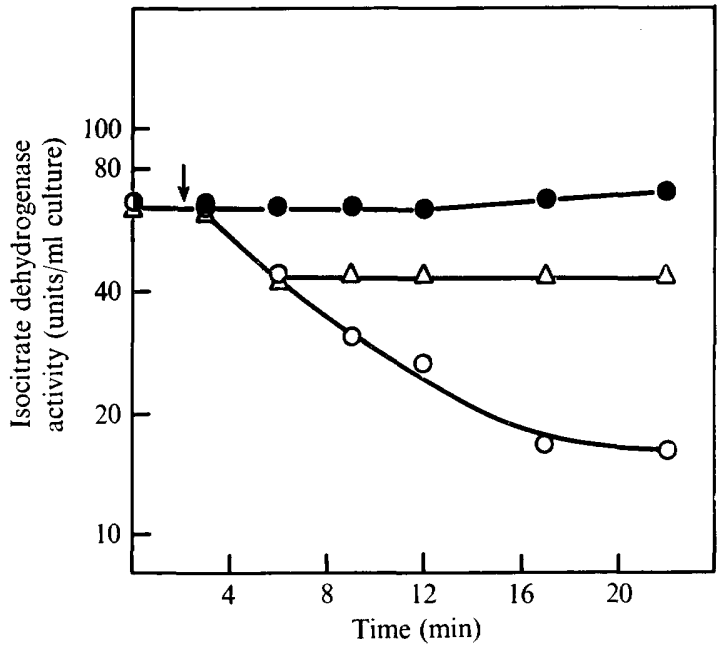

Fig. 2. Isocitrate dehydrogenase activity following addition of acetate, with or without a second carbon source, to cells which had experienced a cycle of loss and recovery of enzyme activity after growth on 2 mM-glucose. $O$, Acetate (I mM) added ( $\downarrow$ ); $\bullet$, acetate (I mM) and pyruvate (I mM) added $(\downarrow) ; \triangle$, acetate (I mM) and malate (I mM) added ( $\downarrow$ ). All additions were made $5 \mathrm{~h}$ after cessation of growth on glucose.

The loss of enzyme activity which followed glucose exhaustion continued for approximately $2 \mathrm{~h}$ (Fig. I), while addition of acetate after recovery of enzyme activity promoted a much more rapid decline (Fig. I) which was complete in approximately I 5 min (Fig. 2). Increasing the acetate concentration by adding extra acetate at the end of growth on glucose did not affect the rate of loss of isocitrate dehydrogenase activity but recovery was delayed. 


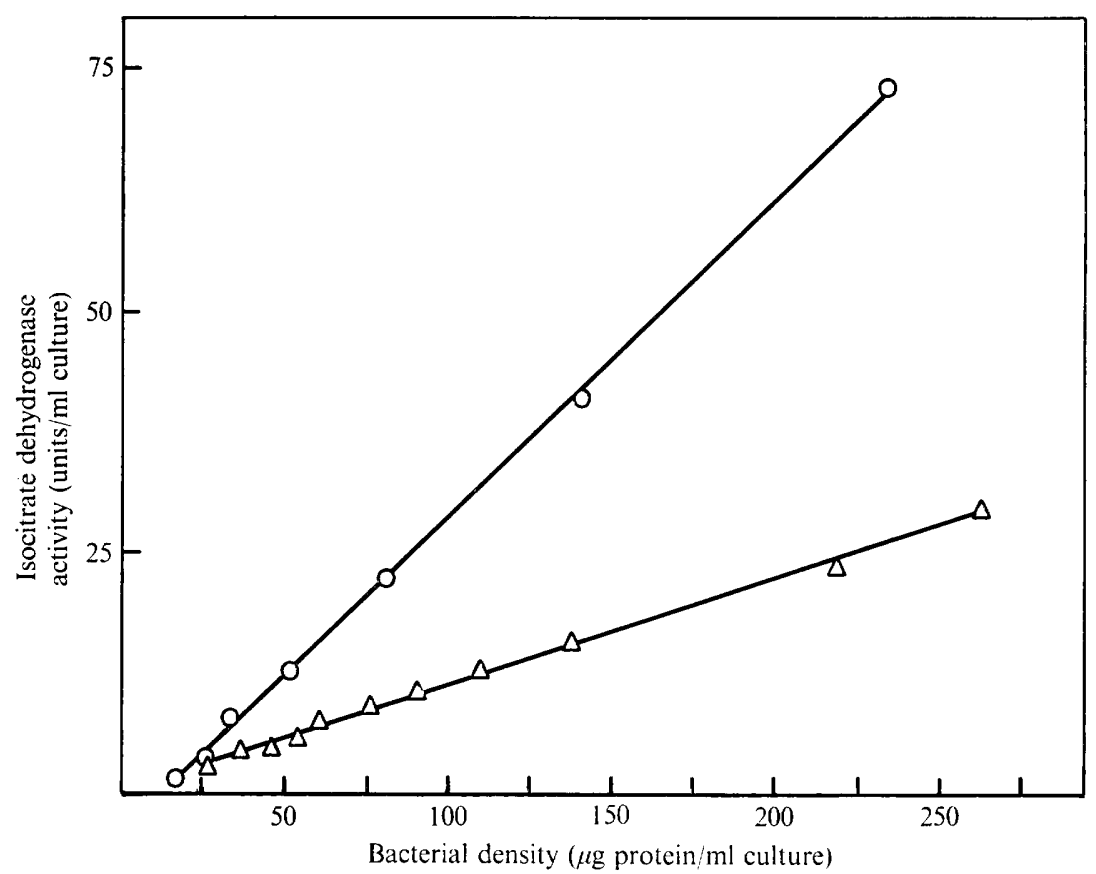

Fig. 3. Differential plots of isocitrate dehydrogenase activity against bacterial protein. $O$, Cells grown on glucose $(2 \mathrm{mM}) ; \Delta$, cells grown on acetate $(30 \mathrm{~mm})$.

Previously we have shown that if one of several intermediary metabolites which alleviate the requirement for the glyoxylate bypass is added at the end of growth on glucose (2 mM), this completely prevents the fall in isocitrate dehydrogenase activity (Holms \& Bennett, I97I). The addition of I mm-pyruvate (or I mm-oxaloacetate; data not shown) simultaneously with acetate, after a cycle of loss and recovery of isocitrate dehydrogenase activity, completely prevented further loss of enzyme activity (Fig. 2). (The action of oxaloacetate may be partially due to some breakdown to pyruvate: Bessman, I957; Swim \& Utter, 1957.) Addition of I mm-malate (or fumarate or succinate; data not shown) plus acetate resulted in a small initial loss, after which enzyme activity was maintained (Fig. 2). The initial loss observed when a dicarboxylic acid was added simultaneously with acetate, in contrast to the complete stability of isocitrate dehydrogenase if pyruvate was added along with acetate, may be due to permeation difficulties encountered by malate, fumarate and succinate (Kay \& Kornberg, 1969). Addition of 2-oxoglutarate with acetate gave a result indistinguishable from that with acetate alone, which again may be due to an inability of 2-oxoglutarate to penetrate quickly into the cell (Kogut \& Podoski, I953; Halpern \& Umbarger, I960).

\section{Isocitrate dehydrogenase during growth on acetate}

Since the variation in isocitrate dehydrogenase activity occurs on adaptation to acetate as sole source of carbon and energy, the state of the enzyme in cells fully adapted to acetate was examined. The apparent activity of isocitrate dehydrogenase during exponential growth on acetate $(30 \mathrm{~mm}$ ) was 270 units $/ \mathrm{mg}$ bacterial protein, compared with $770 \mathrm{units} / \mathrm{mg}$ bacterial protein obtained during growth on glucose ( $2 \mathrm{~mm}$ ) (Fig. 3). When pyruvate 


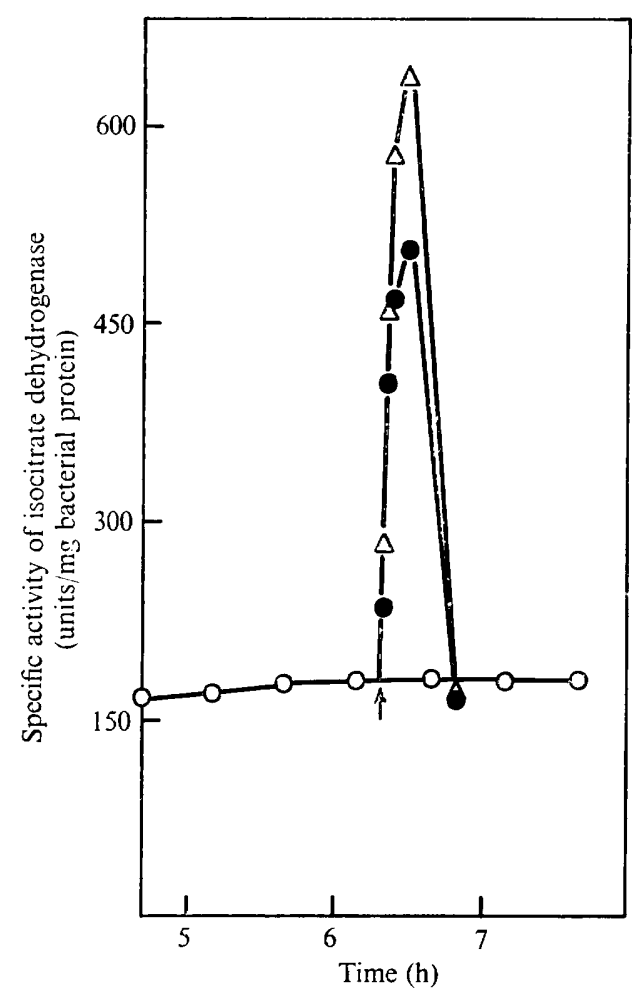

Fig. 4. Isocitrate dehydrogenase activity following the addition of pyruvate ( $\mathrm{mm}$ ), with or without chloramphenicol $(0.3 \mathrm{~mm})$, during growth on $30 \mathrm{~mm}$-acetate. The cells were grown for 24 generations on $30 \mathrm{~mm}$-acetate before inoculation into fresh medium. $\bigcirc$, Control (no addition); $\triangle$, pyruvate (I mM) added $(\uparrow)$;, pyruvate (I mM) and chloramphenicol $(0.3 \mathrm{~mm})$ added $(\uparrow)$; additions were made at a culture density of approximately $125 \mu \mathrm{g}$ bacterial protein $/ \mathrm{ml}$, after 3 to 4 generations of growth in fresh medium. The specific activity of isocitrate dehydrogenase, until $5 \mathrm{~h}$, was maintained between 170 and 195 units $/ \mathrm{mg}$ bacterial protein.

( $1 \mathrm{~mm}$ ) was added to cultures growing on acetate $(30 \mathrm{~mm})$ there was an immediate and rapid 3- to 4-fold increase in isocitrate dehydrogenase activity (Fig. 4) accompanied by an increase in growth rate (the doubling time of the culture decreased from 123 min to $90 \mathrm{~min}$ ). Thirty min after the addition, pyruvate was exhausted and growth rate and enzyme activity reverted to that characteristic of acetate. Chloramphenicol $(0.3 \mathrm{~mm})$, added simultaneously with pyruvate, barely affected the changes in enzyme activity although the maximum activity obtained was somewhat less (Fig. 4).

When glucose ( $2 \mathrm{~mm}$ ) was added to cultures growing on acetate, isocitrate dehydrogenase activity again increased (Fig. 5) but to a lesser extent than after addition of pyruvate. When chloramphenicol $(0.3 \mathrm{~mm})$ was added simultaneously with the sugar, the increase in enzyme activity was almost entirely prevented (Fig. 5). Similar results were obtained when malate (I $\mathrm{mM}$ ) or succinate ( $1 \mathrm{mM}$ ) was added in place of glucose (data not shown).

The cells used in the experiments described above (Figs. 4 and 5) were acetate-adapted before the start of each experiment. Previous results had indicated that adaptation to acetate is required before loss of isocitrate dehydrogenase activity occurs when acetate becomes sole source of carbon and energy (Holms \& Bennett, 1971). Conversely, when glucose is added to acetate-adapted cells a period of adaptation to the sugar may be 


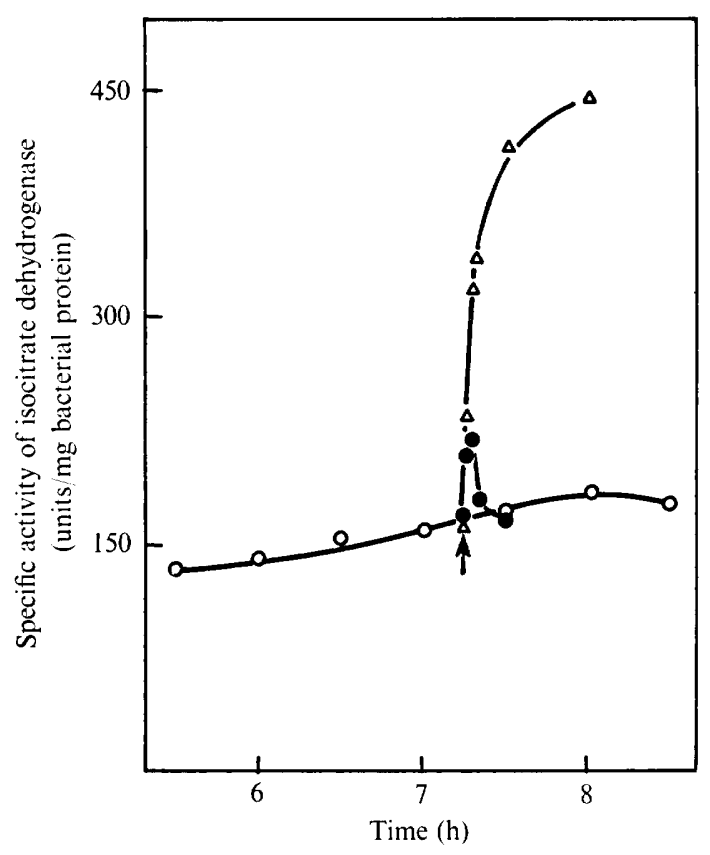

Fig. 5. Isocitrate dehydrogenase activity following the addition of glucose ( $2 \mathrm{~mm}$ ), with or without chloramphenicol $(0.3 \mathrm{~mm})$, during growth on $30 \mathrm{~mm}$-acetate. The cells were grown for 24 generations on $30 \mathrm{~mm}$-acetate before inoculation into fresh medium. $\bigcirc$, Control (no addition); $\Delta$, glucose ( $2 \mathrm{~mm})$ added $(\uparrow)$; $\bigcirc$, glucose $(2 \mathrm{~mm})$ and chloramphenicol $(0.3 \mathrm{~mm})$ added $(\uparrow)$. Additions were made at a culture density of approximately I $25 \mu \mathrm{g}$ bacterial protein $/ \mathrm{ml}$, after 3 to 4 generations of growth in fresh medium. The specific activity of isocitrate dehydrogenase, until $5 \mathrm{~h}$, was maintained between 140 and 195 units/mg bacterial protein.

required before it can be used as a growth substrate and promote an increase in isocitrate dehydrogenase activity. This possibility was examined.

When cells were grown on limited glucose $(2 \mathrm{~mm})$ and acetate $(30 \mathrm{~mm})$ was added $150 \mathrm{~min}$ after exhaustion of the sugar, the cells started to grow immediately (Holms \& Bennett, 197I). After approximately one generation's growth on acetate, glucose, with or without chloramphenicol $(0.3 \mathrm{~mm})$, was added to the culture. In both cases an immediate and rapid increase in isocitrate dehydrogenase activity followed addition of the sugar (Fig. 6). We suggest, therefore, that cells grown on acetate for many generations are unable to use glucose (or malate or succinate), in contrast to pyruvate, without undergoing some form of adaptation. If adaptation is prevented, the presence of glucose does not lead to a stimulation of isocitrate dehydrogenase activity (Fig. 5). However, addition of glucose to cells growing on acetate but able to use the sugar promotes an increase in isocitrate dehydrogenase activity, even in the absence of protein synthesis (Fig. 6).

\section{Isocitrate dehydrogenase activity after removal of acetate}

Only when acetate alone is available has low isocitrate dehydrogenase activity been found in cells possessing the enzymes of the glyoxylate bypass (Holms \& Bennett, I97I). When cells growing on acetate $(30 \mathrm{~mm})$ were deprived of acetate by harvesting and resuspension in a medium devoid of carbon, the activity of isocitrate dehydrogenase increased by 3 - to 4 -fold. 


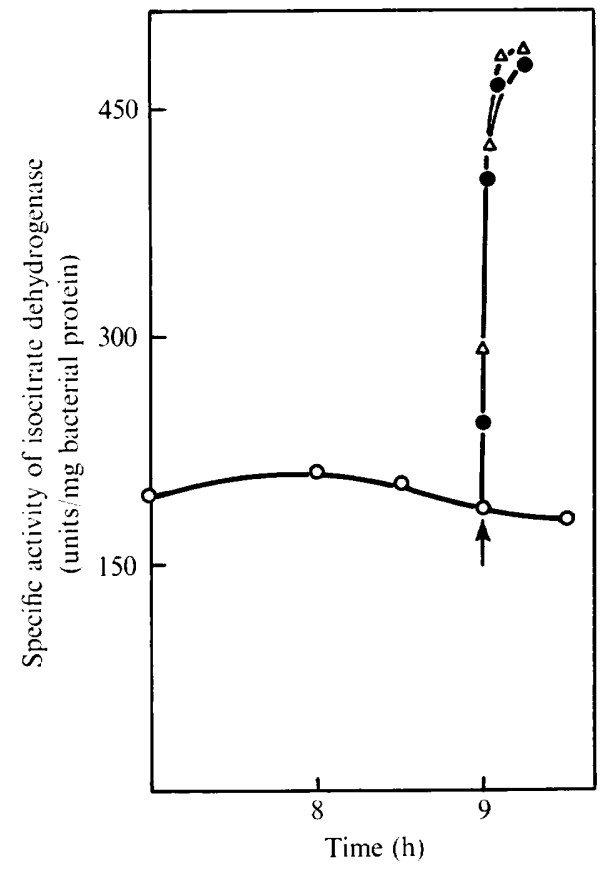

Fig. 6. Isocitrate dehydrogenase activity following the addition of glucose ( $2 \mathrm{~mm})$, with or without chloramphenicol $(0.3 \mathrm{mM})$, during growth on acetate $(30 \mathrm{~mm})$. The cells were grown for 24 generations on 2 mm-glucose (Holms \& Bennett, 1971) and inoculated into limited glucose ( $2 \mathrm{mM}$ )-salts medium; $2 \frac{1}{2} \mathrm{l}$ after growth on glucose ceased $\left(5 \frac{1}{2} \mathrm{~h}\right.$ experimental time), acetate (30 mM) was added to the culture. $\bigcirc$, Control (no addition); $\triangle$, glucose (2 mm) added $(\uparrow) ; \bullet$, glucose $(2 \mathrm{~mm})$ and chloramphenicol $(0.3 \mathrm{~mm})$ added $(\uparrow)$. Additions were made at a culture density of approximately $250 \mu \mathrm{g}$ bacterial protein $/ \mathrm{ml}$, after one generation of growth in acetatesalts medium. The specific activity of isocitrate dehydrogenase, after addition of acetate, was maintained between 190 and 220 units/mg bacterial protein.

This was repeated, except that $\mathrm{I} h$ before the cells were harvested chloramphenicol $(0.3 \mathrm{~mm})$ was added to the culture growing on $30 \mathrm{~mm}$-acetate. Addition of the drug prevented further growth. The cells were harvested by centrifugation (10000 $g$ ) and transferred to fresh media containing chloramphenicol $(0.3 \mathrm{~mm})$, with or without acetate ( $30 \mathrm{~mm}$ ). After transfer of the cells to fresh medium lacking acetate, enzyme activity showed a 3- to 4-fold increase over that in cells transferred to fresh medium containing acetate (Table I). Therefore we suggest that in cells with an active glyoxylate bypass the activity of isocitrate dehydrogenase reflects the availability of acetate as the sole source of carbon in the system.

\section{Comparison of isocitrate dehydrogenase activities}

It has been reported that three electrophoretically-distinct $\mathrm{NADP}^{+}$-specific isocitrate dehydrogenases can be demonstrated in E. coli (Reeves, Brehmeyer \& Ajl, I968), two of which were observed in extracts of glucose-grown cells and one in extracts of acetate-grown cells. Therefore the various enzyme activities found in extracts of $E$. coli ML308, during and after growth on limited glucose $(2 \mathrm{mM})$, were further investigated.

Extracts containing isocitrate dehydrogenase were obtained from cells grown on $2 \mathrm{~mm}$ glucose, (i) when growth ceased and enzyme activity was at a maximum, (ii) I 20 to $150 \mathrm{~min}$ 


\section{Table I. Effect of acetate on isocitrate dehydrogenase activity in chloramphenicol-inhibited, acetate-grown cells}

Chloramphenicol $(0.3 \mathrm{~mm})$ was added to the acetate $(30 \mathrm{~mm})$ growth medium. One h later the cells were harvested by centrifuging ( $10000 \mathrm{~g}$ at $4{ }^{\circ} \mathrm{C}$ for $10 \mathrm{~min}$ ) and resuspended in ice-cold basal salts medium supplemented with chloramphenicol $(0.3 \mathrm{~mm})$, to a turbidity $\left(E_{420}\right)$ of 50.0 . These cells were inoculated into vigorously aerated growth media, at $37{ }^{\circ} \mathrm{C}$. Cell suspensions were diluted I in 2 with $0.3 \mathrm{M}-\mathrm{NaCl}$ containing bovine plasma albumin $(10 \mathrm{mg} / \mathrm{ml})$ before sonication and assay as previously described (Holms \& Bennett, 197I).

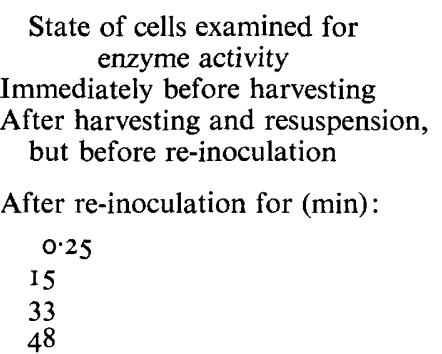

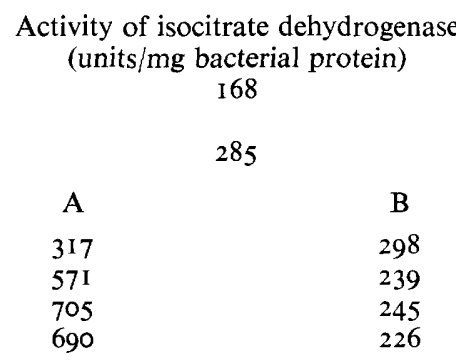

A, cells re-inoculated into basal salts medium supplemented with 0.3 mM-chloramphenicol; $B$, as for A but containing $30 \mathrm{~mm}$-acetate as an additional supplement.

after growth ceased, when enzyme activity had fallen to a minimum and (iii) 240 to $300 \mathrm{~min}$ after growth ceased, when enzyme activity had recovered. Isocitrate dehydrogenase activities in extracts (i), (ii) and (iii) are termed maximum, minimum and recovered, respectively.

\section{Substrate and cofactor requirements of isocitrate dehydrogenase}

Optimum concentrations of isocitrate and NADP ${ }^{+}$for isocitrate dehydrogenase activity in all three extracts were identical. The apparent $K_{m}$ values for substrate and cofactor in these crude extracts are $\mathrm{I} \cdot 65 \times \mathrm{IO}^{-5} \mathrm{M}$ for isocitrate and $2 \cdot \mathrm{I} \times \mathrm{IO}^{-5} \mathrm{M}$ for $\mathrm{NADP}^{+}$, which are in good agreement with those reported for the partially purified enzyme extracted from $E$. coli $\mathrm{E} 26\left(\mathrm{I} .56 \times \mathrm{IO}^{-5} \mathrm{M}\right.$ for isocitrate, and $3.7 \times \mathrm{IO}^{-5} \mathrm{M}$ for $\mathrm{NADP}^{+}$; Reeves, Daumy, Lin \& Houston, 1972) and for the enzyme from other micro-organisms (Ozaki \& Shiio, I968).

\section{pH profile of isocitrate dehydrogenase}

Isocitrate dehydrogenase activity in the three extracts was assayed at various $\mathrm{pH}$ values. The profiles obtained were identical and showed broad peaks of optimal activity with maxima at approximately $\mathrm{pH} 7 \cdot 9$.

\section{Heat sensitivity of isocitrate dehydrogenase}

Isocitrate dehydrogenase in extracts with maximum, minimum and recovered activity was heated for $10 \mathrm{~min}$ at various temperatures. The thermal inactivation profiles obtained with the three extracts were identical (Fig. 7) and showed a $50 \%$ loss of initial activity when heated at $53{ }^{\circ} \mathrm{C}$ (for $10 \mathrm{~min}$ ). Up to $40^{\circ} \mathrm{C}$, isocitrate dehydrogenase was completely stable throughout the $10 \mathrm{~min}$ heating period. 


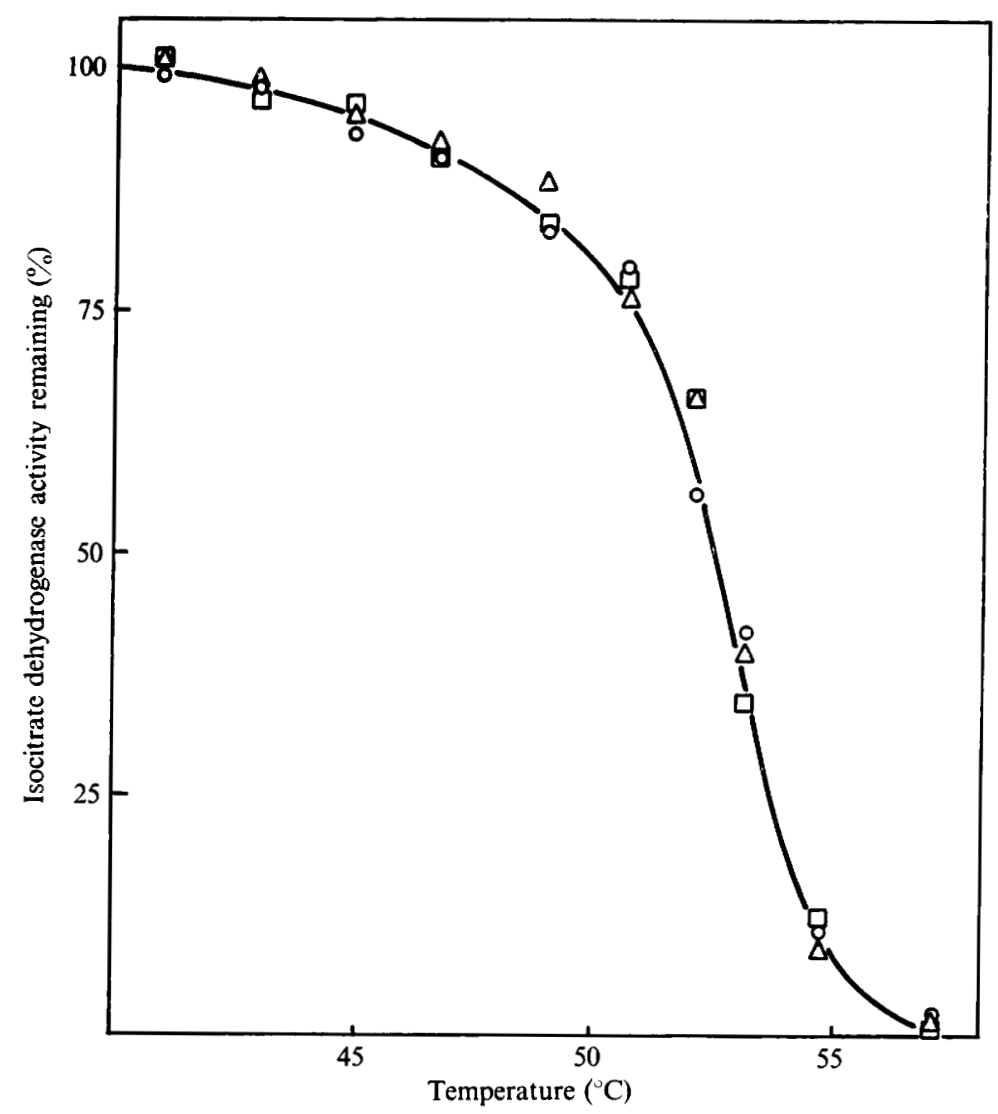

Fig. 7. Effect of heat on isocitrate dehydrogenase activity. $O$, Isocitrate dehydrogenase in maximum activity extracts; $\square$, isocitrate dehydrogenase in minimum activity extracts; $\triangle$, isocitrate dehydrogenase in recovered activity extracts.

\section{Inhibition of isocitrate dehydrogenase}

The NADP+-specific isocitrate dehydrogenase of a number of bacteria is inhibited by a mixture of glyoxylate and oxaloacetate (Shiio \& Ozaki, I968; Marr \& Weber, 1969). We have investigated the effect of several intermediary metabolites, singly and paired, on all three isocitrate dehydrogenase activities described above.

The addition of pyruvate, acetate, succinate, malate or glyoxylate (all at I mM) to extracts containing maximum, minimum and recovered isocitrate dehydrogenase activity had no significant $(< \pm 5 \%)$ effect on isocitrate dehydrogenase activity (Table 2$)$. Oxaloacetate and 2-oxoglutarate (each at $\mathrm{I} \mathrm{mm}$ ) produced 13 and $10 \%$ inhibition of enzyme activity, respectively (Table 2). Pairs of these compounds, with the exception of oxaloacetate plus glyoxylate, gave inhibitions which were additive of those obtained with the individual compounds (Table 2); the mixture of oxaloacetate and glyoxylate inhibited isocitrate dehydrogenase, in all three extracts, by over $90 \%$.

Citrate, cis-aconitate, fumarate (all at I mM) or acetyl-coenzyme A (0.I mM), either alone or paired with one of the other intermediary metabolites tested, did not inhibit isocitrate dehydrogenase in extracts with maximum or minimum activity, and phosphoenolpyruvate, alone or paired with other metabolites, did not affect minimum enzyme activity. 
Table 2. Effect of various intermediary metabolites on isocitrate dehydrogenase in maximum, minimum and recovered activity extracts

Enzyme extracts were incubated for $5 \mathrm{~min}$ at $27^{\circ} \mathrm{C}$ in the assay mix, minus isocitrate and NADP ${ }^{+}$, in the presence of the compound(s), each at I mM. The assay was started by the addition of isocitrate followed by $\mathrm{NADP}^{+}$.

$$
\text { Inhibition of isocitrate dehydrogenase* }(\%)
$$

Addition I

\section{Addition II}

\section{None}

Acetate

Pyruvate

2-Oxoglutarate

Succinate

Malate

Oxaloacetate

Glyoxylate

\begin{tabular}{|c|c|c|}
\hline Acetate & Pyruvate & $\begin{array}{l}\text { 2-Oxo- } \\
\text { glutarate }\end{array}$ \\
\hline 0 & $-I$ & IO \\
\hline- & -2 & 8 \\
\hline-2 & - & 9 \\
\hline 8 & 9 & - \\
\hline 2 & -4 & 9 \\
\hline 0 & -4 & 8 \\
\hline 13 & 12 & 19 \\
\hline 4 & 2 & 13 \\
\hline
\end{tabular}
$*$ Based on $100 \%$ activity being equal to $68 \cdot 5, \mathrm{I} 4 \cdot 2$, and $70 \cdot 0$ units isocitrate dehydrogenase for maximum,
minimum and recovered activity extracts, respectively. The level of inhibition of isocitrate dehydrogenase activity recorded was independent of the extract used.

\section{Table 3. Effect of dialysis on isocitrate dehydrogenase in maximum and minimum activity extracts}

Oxaloacetate $(3.0 \mathrm{~mm})$ and glyoxylate $(3.0 \mathrm{~mm})$ were added to extracts of $2 \mathrm{~mm}$-glucose-grown $E$. coli ML308 possessing either maximum or minimum isocitrate dehydrogenase activity. On assay, inhibitors were diluted to $\mathrm{I} \cdot 0 \mathrm{mM}$. Inhibited and non-inhibited cell extracts were dialysed for $18 \mathrm{~h}$ against $1000 \mathrm{vol} .0 \cdot 15 \mathrm{M}-\mathrm{NaCl}$, at $4{ }^{\circ} \mathrm{C}$, and then assayed as previously described (Holms \& Bennett, I97I).

\begin{tabular}{|c|c|c|c|c|}
\hline \multirow{3}{*}{$\begin{array}{l}\text { Treatment to which extract } \\
\text { was subjected }\end{array}$} & \multicolumn{4}{|c|}{ Isocitrate dehydrogenase activity } \\
\hline & \multicolumn{2}{|c|}{$\begin{array}{c}\text { Maximum activity } \\
\text { extract }\end{array}$} & \multicolumn{2}{|c|}{$\begin{array}{l}\text { Minimum activity } \\
\text { extract }\end{array}$} \\
\hline & $\begin{array}{l}\text { Units } \\
\text { per mg } \\
\text { bacterial } \\
\text { protein }\end{array}$ & $\begin{array}{l}\text { Percentage } \\
\text { initial } \\
\text { activity }\end{array}$ & $\begin{array}{l}\text { Units } \\
\text { per mg } \\
\text { bacterial } \\
\text { protein }\end{array}$ & $\begin{array}{l}\text { Percentage } \\
\text { initial } \\
\text { activity }\end{array}$ \\
\hline None & 389 & 100 & 126 & 100 \\
\hline Dialysis & 340 & 87 & 115 & $9 \mathrm{I}$ \\
\hline $\begin{array}{l}\text { Inhibition with } 3.0 \mathrm{~mm}- \\
\quad \text { glyoxylate }+3.0 \mathrm{~mm} \text {-oxaloacetate }\end{array}$ & 6 & $\mathrm{I} \cdot 6$ & 0 & 0 \\
\hline $\begin{array}{l}\text { Inhibition with } 3.0 \mathrm{~mm} \text { - } \\
\text { glyoxylate }+3.0 \mathrm{~mm} \text {-oxaloacetate, } \\
\text { followed by dialysis }\end{array}$ & 190 & 49 & 62 & $49 \cdot 5$ \\
\hline
\end{tabular}

No compounds, singly or in pairs, activated isocitrate dehydrogenase.

When equal volumes of extracts with maximum or minimum isocitrate dehydrogenase activity were mixed, enzyme activity in the combined extract was equal to the sum of the activities of the individual components of the mixture (to within $\pm 2 \%$ ). Similar results were obtained when extracts with minimum and recovered or with maximum and recovered activity were mixed before assay. 
Table 4. Loss and recovery of isocitrate dehydrogenase activity in various organisms after growth on limited glucose

All organisms, with the exception of CP55 which is auxotrophic for thymine, are prototrophs and were grown in $2 \mathrm{~mm}$-glucose-minimal salts medium, which was supplemented with $50 \mu \mathrm{g}$ thymine/ $\mathrm{ml}$ to support growth of $\mathrm{CP} 55$.

Specific activity of isocitrate dehydrogenase (enzyme units/turbidity unit at $E_{4 \varepsilon 0}$ )

\begin{tabular}{|c|c|c|c|c|}
\hline Organism & Strain* & Maximum & Minimum & Recovered \\
\hline Escherichia coli $\mathbf{\text { в }}$ & Asig† & 90 & 8 & 68 \\
\hline E. coli $\mathrm{B} / \mathrm{r}$ & CPI4 & 80 & 9 & $5 \mathrm{I}$ \\
\hline E. coli $\mathrm{C}$ & CP29 & 68 & 5 & 26 \\
\hline E. coli Crookes & ATCC 8739 & 102 & 19 & 62 \\
\hline E. coli $\mathrm{KI} 2$ & CP55 & 88 & 74 & 83 \\
\hline E. coli $\mathrm{KI} 3$ & CP56: & 128 & 112 & 118 \\
\hline E. coli ML 308 & ATCCI 5224 & 98 & I I & 55 \\
\hline Salmonella typhimurium & CPI2OI & 70 & II & 30 \\
\hline Aerobacter aerogenes & CPI 227 & 72 & 11 & $3 I$ \\
\hline Serratia marcescens & CPI 233 & $8 I$ & 19 & 50 \\
\hline
\end{tabular}

* All CP strains were kindly supplied by the University Institute of Microbiology, Copenhagen.

$\dagger$ As described by Sekiguchi \& lida (1967).

$\ddagger$ Escherichia coli $\mathrm{KI} 3$ is a prototrophic $\mathrm{KI} 2$, cured of $\lambda$.

Relief of the concerted inhibition produced by oxaloacetate plus glyoxylate

Maximum or minimum activity extracts inhibited with a mixture of oxaloacetate and glyoxylate (both at I $\mathrm{mm}$ ) regained a large fraction $(50 \%)$ of their uninhibited activity on dialysis (Table 3). Dialysis of the uninhibited extracts caused a slight loss of enzyme activity.

The concerted inhibition by oxaloacetate plus glyoxylate was also relieved by $25 \%$ in both kinds of extract on increasing the isocitrate concentration in the assay twofold. A similar increase in substrate concentration did not increase enzyme activity in extracts not inhibited with oxaloacetate and glyoxylate.

\section{Loss and recovery of isocitrate dehydrogenase activity, following growth on limited glucose, in various organisms}

The behaviour of isocitrate dehydrogenase activity in a number of different organisms after cessation of growth on limited glucose ( $2 \mathrm{mM}$ ) has been examined (Table 4$)$. Loss and subsequent recovery of enzyme activity was demonstrated in 5 out of 7 strains of $E$. coli tested, namely $E$. coli $\mathrm{B}, \mathrm{B} / \mathrm{r}$, C, Crookes, and ML308. No loss of activity was apparent in either of the strains of $E$. coli KI 2 examined. We were also able to demonstrate loss and recovery of isocitrate dehydrogenase activity in Salmonella typhimurium, Klebsiella aerogenes and Serratia marcescens.

\section{DISCUSSION}

Conditions required for loss of isocitrate dehydrogenase activity. Addition of chloramphenicol, at the end of growth on glucose, prevented adaptation to the acetate which is accumulated during growth on the sugar (Britten, I954; Holms \& Bennett, I97I). The cycle of loss and recovery of isocitrate dehydrogenase activity which normally follows glucose exhaustion was also prevented (Fig. I). Addition of the drug simultaneously with 
acetate to cells which had already undergone a cycle of loss and recovery of isocitrate dehydrogenase activity, and therefore were partially adapted to acetate (Holms \& Bennett, I97I), did not prevent a further very rapid loss of enzyme activity (Fig. 2), which again recovered some time later (Fig. I). On the other hand, if one of several intermediary metabolites, whose utilization makes the glyoxylate bypass redundant, was added to similarly adapted cells simultaneously with acetate, this did inhibit further loss of isocitrate dehydrogenase activity (Fig. 2).

These results support our previous conclusion that the low isocitrate dehydrogenase activity observed after exhaustion of glucose is a result of the operation of the glyoxylate bypass (Bennett \& Holms, 1970; Holms \& Bennett, 1971), an essential pathway when acetate is the source of both carbon and energy (Kornberg, 1966). The results (Fig. I) also indicate that recovery of enzyme activity proceeded in the absence of protein synthesis.

Growth on acetate. The status of isocitrate dehydrogenase in cells growing for many generations on acetate as sole source of carbon and energy was investigated, and cursory examination suggested that enzyme synthesis during growth on acetate was repressed by $65 \%$ relative to glucose (Fig. 3). However, the rapid increase in enzyme activity observed after the addition of pyruvate (Fig. 4), even in the presence of chloramphenicol, indicates that the cells contained a large amount of enzyme protein maintained in an inactivated, or inhibited, state. Pyruvate and the other compounds tested (malate, succinate and glucose; Figs. 4, 5 and 6) which promoted an increase in enzyme activity are themselves products of the glyoxylate bypass or are metabolized more readily than acetate to such products. These products have been shown to inhibit isocitrate lyase and so inhibit the operation of the glyoxylate bypass (Ashworth \& Kornberg, I963; Kornberg, I966; Kornberg, Collins \& Bigley, 1960).

Thus, once more, we conclude that as long as the glyoxylate bypass operates to supply low molecular weight precursors for macromolecular synthesis, isocitrate dehydrogenase is maintained in a partially inactivated state. When metabolism via the glyoxylate bypass ceases, isocitrate dehydrogenase activity is increased by a mechanism which does not depend upon de novo synthesis of enzyme protein. Consistent with this is the observation that activation of isocitrate dehydrogenase in acetate-grown cells was achieved by simply removing acetate from the medium, even in chloramphenicol-inhibited cultures (Table I).

Isocitrate dehydrogenase in maximum, minimum and recovered activity extracts. Although the increase in isocitrate dehydrogenase activity observed cannot be explained by de novo synthesis it could still involve the activation of an already synthesized, but latent, isoenzyme. However, optimum conditions for assay of isocitrate dehydrogenase in extracts showing maximum, minimum and recovered activity are identical for substrate, cofactor and $\mathrm{pH}$ of assay. Furthermore, when the enzyme in the three extracts was heated the inactivation profiles obtained were identical (Fig. 7). These results indicate that the isocitrate dehydrogenase activities in all three extracts were indistinguishable on the basis of these parameters and strongly suggest that the same enzyme was involved at each stage of the cycle of variation in enzyme activity.

Inhibition of isocitrate dehydrogenase. Our results confirm those of Shiio \& Ozaki (I968) and Marr \& Weber (1969) in that the NADP+ ${ }^{+}$-specific isocitrate dehydrogenase of $E$. coli ML308 was strongly inhibited by a mixture of glyoxylate and oxaloacetate (Table 2). It has been postulated that this concerted inhibition acts to co-ordinate the activities of the glyoxylate bypass and the tricarboxylic acid cycle (Shiio \& Ozaki, 1968) and in principle could be responsible for the low enzyme activities observed in cells with an operating 
glyoxylate cycle. However, isocitrate dehydrogenase in extracts exhibiting either maximum or minimum activity was inhibited to the same degree by a mixture of glyoxylate and oxaloacetate, and this inhibition was relieved to an equal extent, in both instances, by dialysis (Table 3 ). Furthermore, the concerted inhibition by glyoxylate plus oxaloacetate could partially be relieved by increasing the substrate concentration in the assay mixture. In contrast, neither dialysis nor an increased substrate concentration altered isocitrate dehydrogenase activity in extracts showing minimal or maximum activity.

Thus, we consider it unlikely that loss of enzyme activity is due to inhibition by glyoxylate plus oxaloacetate or by any other low molecular weight compounds, unless by some which have not been tested and which are so tightly bound as to resist dialysis. Further, it is unlikely that high enzyme activity depends on a low molecular weight stimulator because such extracts lost little activity (13\%) on dialysis and because low activity extracts were not stimulated by any of the compounds tested. Finally, mixtures of extracts of the three different activities all yielded simple additive results, again suggesting that the variation in enzyme activity is not mediated by a small, diffusible compound.

Mechanism of inactivation of isocitrate dehydrogenase. The evidence indicates that the changes in the activity of isocitrate dehydrogenase observed during shifts to and from media containing acetate as sole source of carbon and energy are independent of protein degradation and de novo synthesis and do not appear to be affected by freely dissociable, low molecular weight potentiators of enzyme action. This would tend to eliminate models in which changes in enzyme activity are dependent on an induction-repression type of mechanism or in which enzyme activity is regulated solely through inhibition by small, intermediary metabolites such as glyoxylate and oxaloacetate (Shiio \& Ozaki, I968; Marr \& Weber, 1969). The results do not, however, rule out some form of reversible inactivation. This could be achieved through changes in the secondary structure of the enzyme protein effected by covalent attachment of some small group, as has been shown for phosphorylase (Brown \& Cori, I96I) and glutamine synthetase (Shapiro \& Stadtman, 1970), or through association with some macromolecule, as exemplified by yeast ornithine carbamoyltransferase (Béchet \& Wiame, I965; Messenguy, Béchet \& Wiame, I967; Messenguy \& Wiame, I969).

General occurrence of loss and recovery of isocitrate dehydrogenase activity after growth on limited glucose. The finding that isocitrate dehydrogenase activity was lost and subsequently recovered, after growth on limited glucose, in $E$. coli B, B/r, C, Crookes and ML308, as well as in Salmonella typhimurium, Klebsiella aerogenes and Serratia marcescens (Table 4) suggests that the phenomenon is a widespread one, at least within the enteric group of bacteria. Hadjipetrou, Gerrits, Teulings \& Stouthamer (1964) have reported that acetate accumulates in the medium of $K$. aerogenes during growth on glucose and is subsequently utilized when glucose is exhausted. This is analogous to our finding with E. coli (Holms \& Bennett, I97I). Hence it is reasonable to suggest that in E. coli and $K$. aerogenes loss of isocitrate dehydrogenase activity occurs when the cell must use acetate as sole source of carbon and energy and so must possess an active glyoxylate bypass.

The absence of any loss of isocitrate dehydrogenase activity in the two KI2 strains of $E$. coli tested cannot be attributed to a lack of production of acetate during growth on glucose, as addition of acetate $(2 \mathrm{~mm}) 2 \mathrm{~h}$ after growth on glucose ceased failed to promote a loss of enzyme activity (Bennett, unpublished results). Whether this inability to inactivate isocitrate dehydrogenase confers a disadvantage on these strains during shifts to and from acetate medium has so far not been examined.

These data provide further support for the hypothesis (Holms \& Bennett, I97I) that 
inactivation of isocitrate dehydrogenase is a mechanism whereby utilization of isocitrate via the glyoxylate bypass is favoured when operation of this pathway, for the provision of $\mathrm{C}_{4}$-dicarboxylic acids (Kornberg, 1966), is indispensible if further growth is to occur. Furthermore, the mechanism employed confers the additional advantage that an improvement in the nutritional situation elicits an extremely rapid restoration of the full capacity of the tricarboxylic acid cycle.

Thanks are due to the Medical Research Council for a research studentship awarded to P.M.B. during the initial part of this work and to The Wellcome Trust for a postdoctoral research fellowship awarded to P.M.B. during the latter part of the work. The investigation was supported in part by grants from the Science Research Council, Medical Research Council and The Royal Society.

\section{REFERENCES}

Ashworth, J. M. \& Kornberg, H. L. (1963). Fine control of the glyoxylate cycle by allosteric inhibition of isocitrate lyase. Biochimica et biophysica acta 73, 5I9-522.

BÉCHET, J. \& WIAME, J. M. (I965). Indication of a specific regulatory binding protein for ornithine transcarbamylase in Saccharomyces cerevisiae. Biochemical and Biophysical Research Communications 2r, 226-234.

Bennett, P. M. \& Holms, W. H. (1970). Regulation of isocitrate dehydrogenase activity in Escherichia coli by the operation of the glyoxylate cycle. Journal of General Microbiology $6 \mathbf{r}$, ix-x.

Bessman, S. P. (I957). Preparation and assay of oxalacetic acid. In Methods in Enzymology, vol. 3, pp. 418-42I. Edited by S. P. Colowick and N. O. Kaplan. New York: Academic Press.

Britten, R. J. (I954). Extracellular metabolic products of Escherichia coli during rapid growth. Science, New York II9, 578.

Brown, D. H. \& CorI, C. F. (196I). Animal and plant polysaccharide phosphorylases. In The Enzymes, vol. 5, pp. 207-228. Edited by P. D. Boyer, H. Lardy and K. Myrbäck. New York and London: Academic Press.

Hadjipetrou, L. P., Gerrits, J. P., Teulings, F. A. G. \& Stouthamer, A. H. (1964). Relation between energy production and growth of Aerobacter aerogenes. Journal of General Microbiology 36, I39-150.

Halpern, Y.S. \& UMbarger, H. E. (1960). Conversion of ammonia to amino groups in Escherichia coli. Journal of Bacteriology 8o, 285-288.

Holms, W. H. \& BennetT, P. M. (I97I). Regulation of isocitrate dehydrogenase activity in Escherichia coli on adaptation to acetate. Journal of General Microbiology 65, 57-68.

Kay, W. W. \& KornberG, H. L. (1969). Genetic control of the uptake of $\mathrm{C}_{4}$-dicarboxylic acids by Escherichia coli. FEBS Letters 3, 93.

Kogut, M. \& Podoski, E. P. (1953). Oxidative pathways in a fluorescent Pseudomonas. Biochemical Journal 55, 800-8I I.

Kornberg, H. L. (1966). The role and control of the glyoxylate cycle in Escherichia coli. Biochemical Journal 99, I-I I.

Kornberg, H. L., Collins, J. F. \& Bigley, D. (1960). The influence of growth substrates on metabolic pathways in Micrococcus denitrificans. Biochimica et biophysica acta 39, 9-24.

MARr, J. J. \& Weber, M. M. (I969). Concerted inhibition of a NADP ${ }^{+}$-specific isocitrate dehydrogenase and the implications for metabolic regulation. Biochemical and Biophysical Research Communications 35, $12-19$.

Messenguy, F., Béchet, J. \& Wiame, J. M. (1967). Étude de l'action d'une protéine régulatrice de l'activité de l'ornithine-carbamoyltransférase de Saccharomyces cerevisiae. Archives internationales de physiologie et de biochimie 75, 889-89I.

Messenguy, F. \& Wiame, J. M. (I969). The control of ornithine-transcarbamylase activity by arginase in Saccharomyces cerevisiae. FEBS Letters 3, 47-49.

OzAKI, H. \& SHIIO, I. (I968). Regulation of the TCA and glyoxylate cycles in Brevibacterium flavum. Journal of Biochemistry 64, 355-363.

Reeves, H. C., Brehmeyer, B. A. \& AJl, S. J. (1968). Multiple forms of bacterial NADP ${ }^{+}$-specific isocitrate dehydrogenase. Science, New York 162, 359-360. 
Reeves, H. C., Daumy, G. O., Lin, C. C. \& Houston, M. (1972). NADP ${ }^{+}$-specific isocitrate dehydrogenase of Escherichia coli. I. Purification and characterization. Biochimica et biophysica acta 258, 27-39.

SeKIGUChI, M. \& IIDA, S. (I967). Mutants of Escherichia coli permeable to actinomycin. Proceedings of the National Academy of Sciences of the United States of America 58, 2315-2320.

Shapiro, B. M. \& Stadtman, E. R. (1970). The regulation of glutamine synthesis in microorganisms. Annual Review of Microbiology 24, 50 I-524.

ShIIO, I. \& OzAKI, H. (1968). Concerted inhibition of isocitrate dehydrogenase by glyoxylate plus oxalacetate. Journal of Biochemistry 64, 45-53.

Swim, H. E. \& UTTER, M. F. (I957). Isotopic experimentation with intermediates of the tricarboxylic acid cycle. In Methods in Enzymology, vol. 4, pp. 584-609. Edited by S. P. Colowick and N. O. Kaplan. New York: Academic Press. 